\title{
Secular Trends in Self-Assessed Health Over 24 Years Among 38-, 50-, 70- and 75-Year-Old Women: Observations from the Prospective Population Study of Women in Gothenburg
}

This article was published in the following Dove Press journal:

International Journal of General Medicine

\author{
Sofia Jönsson' \\ Dominique Hange ${ }^{2,3}$ \\ 'Region Vastra Gotaland, Sahlgrenska \\ University Hospital, Gothenburg, \\ Sweden; ${ }^{2}$ Primary Health Care/School of \\ Public Health and Community Medicine, \\ Institute of Medicine, Sahlgrenska \\ Academy, University of Gothenburg, \\ Gothenburg, Sweden; ${ }^{3}$ Narhalsan \\ Research and Development Primary \\ Health Care, Region Vastra Gotaland, \\ Gothenburg, Sweden
}

Background: Throughout the world, women report poorer self-assessed health than men. In Sweden, women's life circumstances have changed on many levels during the past decades. While cognition and bodily health have improved, mental health has deteriorated. During the 1980s and 1990s, Swedish women's self-rated health was deteriorating with an increase of psychosomatic diseases. Common mental disorders have increased most rapidly and contributed to an increase in sick leaves.

Purpose: The aim of this study was to study secular trends in self-assessed health in SF-36, in three different cohorts of women examined in 1992-1993, 2000-2001, 2004-2006 and 2016-2017.

Participants and Methods: Data from the Population Study of Women in Gothenburg were used where 38-, 50-, 70- and 75-year-old women had responded to SF-36 over a period of 24 years. SF-36 is a questionnaire concerning self-assessed health that consists of eight different subcategories, ie, four about physical health and four about mental health. This study made a comparison between the different results in SF-36 during 24 years.

Results: Results showed that today's 38-year-old women had poorer self-rated health in four subcategories, social functioning (SF), mental health (MH), vitality (VT) and general health (GH), compared to 24 years ago. Fifty-year-old women rated their health better in one subcategory, physical functioning (PF), and worse in another subcategory, VT. Seventyyear-old women rated their health better in two subcategories, physical role (RP) and emotional role (RE).

Conclusion: This study indicates that poor mental health is increasing among middle-aged women and that increased mental stress levels can be an underlying factor.

Keywords: mental stress, population study, self-assessed health, SF-36, women's health

\section{Introduction}

Worldwide, women report poorer self-assessed health than men, as indicated by international comparisons between countries based on data from the World Health Organization's (WHO) surveys. ${ }^{1}$ During the 1980s and 1990s, Swedish women's selfassessed health deteriorated with an increase in psychosomatic disorders. ${ }^{2}$ A combination of social factors and biological factors is believed to underlie the major gender differences observed in all regions of the world. ${ }^{3,4}$ Physical health has improved, and the expected life span has increased, but the same positive trend in mental health has
Correspondence: Dominique Hange Primary Health Care/School of Public Health and Community Medicine, Institute of Medicine, Sahlgrenska Academy, University of Gothenburg, PO Box 454, SE-405 30, Gothenburg 700 Sweden

Tel +46722 245700

Email dominique.hange@vgregion.se 
not been demonstrated. While morbidity and mortality are higher in men, self-assessed health is reported to be lower in women. ${ }^{5}$ In Sweden, the life circumstances of women have changed in many ways in recent decades due to societal developments. A larger proportion of today's women have higher education and are to a greater extent full-time employee. During the economic crisis of the 1990s, women born in the early 1970s began to study at universities and colleges to a much greater extent than before. Approximately 200,000 students were enrolled in Swedish universities and colleges in the 1990s; today the figure is over 400,000 and more than $50 \%$ of these are women. ${ }^{6}$ In $2016,19 \%$ of women in Sweden between 16 and 84 years reported reduced mental well-being compared with $13 \%$ of all men. ${ }^{7}$ Anxiety and stress-related mental disorder belong to the group of diagnoses that are most pronounced and are responsible for an increasing sickness absence among women. The number of women on sick leave in 2016 was almost double compared with the number of men. ${ }^{8}$ Since the mid-1990s, the amount of long-term sick leave has increased in women, and in Sweden, Common Mental Disorders (CMD) are responsible for the majority of all sick leave. ${ }^{9}$ Earlier studies have shown that patients on long-term sick leave report poorer self-assessed health compared to patients on short-term sick leave. ${ }^{10}$

By following women over time and identifying trends in self-assessed health, it is possible facilitate future planning and design of healthcare and care, it is relevant to know in which areas women experience both improved and impaired health.

The aim of this study was to study secular trends in self-assessed health by SF-36 in three different cohorts of women examined in 1992-93, 2000-01, 2004-06 and 2016-17 from the prospective Population Study of Women in Gothenburg, Sweden (PSWG). As prevalence of mental health problems have increased worldwide, the hypothesis was that the self-assessed mental health is worse among women who participated in the study 2016-17 compared to the women who participated in 1992-93.

\section{Participants and Methods The Population Study of Women in Gothenburg}

In 1968-69, 1462 women aged 38, 46, 50, 54 and 60 in Gothenburg, Sweden, participated in PSWG. After that follow-up examinations have been executed in 1974-74, 1980-81, 1992-93, 2000-01, 2004-05, 2005-06 and in
2016-2017. In the two latest examinations, new cohorts of 38- and 50-year-old women participated. The participant rate has been high through all the years, ie, around $90 \%$ at the three first examinations and around $70 \%$ in the later examinations (see Table 1). Details of the sampling procedure and participation rates at earlier examinations have been presented elsewhere. ${ }^{11-14}$

Data in this study were collected from 1992 (when the SF-36 began to be used in the population study) and at all later examinations. Table 1 shows year of the study, year of birth, ages, number of participants at each follow up as well as number of SF-36 survey completed at each follow up, from 1992-1993 to 2016-2017. In the study 2000-01 only 70 - year-old women participated. In the studies 2004-06 the women were 38-, 50-, and 75-years-old.

\section{Self-Assessed Health and SF-36}

The health survey, Medical Outcomes Study Questionnaire Short Form 36 Health (SF-36) originates from the New England Medical Center in Boston and Rand Corporation in Santa Monica. ${ }^{15}$ The idea was that health would not only be based on morbidity and mortality but also on the patient's own view of quality of life. The survey measures how well-functioning the patient is in everyday life. The 36 questions that constitute the survey take an average of 10 minutes to answer. The SF-36 is suitable for grouplevel analysis for a general population. Since the form is not specified for any disease group, the SF-36 is also suitable for comparisons between disease groups. It can also be a useful instrument in the clinic for following a patient's development over time. ${ }^{15,16}$ Most of the studies that examined the reliability of the SF-36 have exceeded $0.80 .{ }^{17}$ Estimates of reliability in the physical and mental health sections are above 0.90 . The SF-36 is well validated, ${ }^{17}$ also for Swedish conditions during the 1990s. ${ }^{18-20}$ The 36 questions are divided into eight different sections: physical functioning $(\mathrm{PF}=$ opportunity to perform daily activities), physical role $(\mathrm{RP}=$ limitation in activities due to bodily health), bodily pain ( $\mathrm{BP}=$ the amount of pain and its influence in everyday life), general health (GH), vitality (VT = energy level, sense of fatigue and depression), social functioning ( $\mathrm{SF}=$ affecting social activities due to bodily health or emotional problems), emotional role $(\mathrm{RE}=$ limitation in activities due to emotion or emotional problems), and mental health $(\mathrm{MH}=$ emotional well-being). SF-36 gives a total score for each of the included subscales. The sections contain 2-10 questions with 2-6 response options. The scales are scored so 
Table I Year of the Study, Year of Birth, Ages, Participant Rates as Well as Number of SF-36 Survey Completed at Each Follow-Up, from 1992-1993 to 2016-2017

\begin{tabular}{|l|l|l|l|l|}
\hline Year of Study & Ages & $\begin{array}{l}\text { Invited Women } \\
\mathbf{n}\end{array}$ & $\begin{array}{l}\text { Non-Participants/ } \\
\text { Unreachable and } \\
\text { Language Difficulties } \\
\mathbf{n}\end{array}$ & $\begin{array}{l}\text { SF 36 Form Completed } \\
\mathbf{n}(\%)\end{array}$ \\
\hline $1992-1993$ & 70 & 473 & $\begin{array}{l}183 \\
28\end{array}$ & $290(61)$ \\
& 50 & 127 & 24 & $99(78)$ \\
& 92 & 235 & $457(66)$ \\
\hline Total & 38 & 692 & 171 & $252(60)$ \\
\hline $2000-2001$ & 70 & 423 & 171 & $252(60)$ \\
Total & & 423 & 216 & $289(57)$ \\
\hline $2004-2005$ & 50 & 505 & 139 & $204(60)$ \\
& 38 & 343 & 185 & $238(56)$ \\
$2005-2006$ & 75 & 423 & 540 & $307(59)$ \\
Total & & 1271 & 216 & $262(51)$ \\
\hline $2016-2017$ & 50 & 523 & 253 & $569(55)$ \\
\hline Total & 38 & 515 & 469 & $2009(59)$ \\
\hline Total & & 1038 & & \\
\hline $1992-2017$ & & 3424 & & \\
\hline
\end{tabular}

that a higher score always indicates better health status. The scoring takes place in several steps and requires the use of tables in the manual. ${ }^{21}$ The original points and the points for each sub-scale are summed. Then the scores on all subscales are converted to $0-100$, higher scores indicate less disability; I e, a score of zero is equivalent to maximum disability and a score of 100 is equivalent to no disability. All calculations were done in a computer program using the algorithms for calculating points based on the manual's instructions.

The eight subcategories that make up SF-36 can be summarized in the Mental Component Summary (MCS) and Physical Component Summary (PCS) groups. MCS includes VT, SF, RE and MH while PCS includes PF, RP, $\mathrm{BP}$ and $\mathrm{GH} .^{21,22}$

The questionnaire also includes a question concerning change of health in the past 12 months. Thirty-eight- and fifty-year-old women completed SF-36 in 1992, 2004 and 2016. Seventy-year women completed it in 1992 and 2000 while women born in 1930 completed SF-36 in 2000 and 2005, when 70- and 75-years-old.

\section{Socio-Economic Status}

Information about marital status, children, total income status and education was obtained by means of a questionnaire and transformed into a measure of socioeconomic status (SES). SES was defined according to a five-point scale. ${ }^{23,24}$ For the purpose of this study, high SES was defined as large-scale employers and officials of high or intermediate rank, intermediate SES was defined as small-scale employers, officials of lower rank, and foremen, while low SES was defined as skilled and unskilled workers. Education was divided into three categories; elementary school (usually six or seven years), upper secondary school and university.

\section{Physical Activity}

On the basis of the physician's interview with the women, they were classified as being physically active during leisure time, if they reported usually, during the last 12 months, spending more than four hours a week gardening, running, dancing, playing golf, tennis, or similar activities.

\section{Alcohol Habits}

Information regarding alcohol habits was obtained at every examination using the same standardized structured interview conducted by a physician. All participants were asked to report their intake frequency (not in grams/day or drinks/week) of three different types of alcoholic drinks, namely, beer, wine, and spirits. Women were asked to 
report the frequency of alcohol intake according to the following answer alternatives:

1. Never.

2. Earlier, but not during the last 10 years.

3. Earlier, but not during the last year.

4. Monthly.

5. Weekly.

6. Several times a week.

7. Daily.

For the purpose of this study we derived three separate categories of consumption of alcohol, based on the various levels (frequency) where:

(i) "Never" included levels 0,1 and 2.

(ii) "Sometimes" included levels 3 and 4.

(iii) "Regularly" included levels 5 and 6.

\section{Mental Stress}

Prevalence of mental stress was based on a question describing the extent to which the women had experienced mental stress previously or presently. The mental stress question was asked in exactly the same way at all examinations: Have you experienced any period of mental stress (one month or more), and with mental stress we mean that you have been irritable, tense, nervous, anxious, afraid, anguished or sleepless connected with concern for your work, health, family or conflict with the people around you (at home, at work).

1. Never experienced mental stress

2. Experienced mental stress, but not during the last 5 years

3. Occasionally experienced mental stress during the last 5 years

4. Experienced mental stress several times during the last 5 years

5. Experienced mental stress constantly during the last year

6. Experienced mental stress constantly during the last 5 years

For the purpose of this study we derived three separate categories of mental stress, based on the various levels (frequency) where:

i) "Never" included levels 0 and 1

ii) "Sometimes" included level 2 iii) "Regularly" included levels 3, 4 and 5

\section{Statistical Methods}

For 38- and 50-year olds, ANOVA analyses were conducted to test differences between mean values for each subcategory. The 70-year olds were made up of two groups, born in 1922 and 1930; therefore, independent samples were used to test differences. The 75 -year olds who responded to the SF-36 in 2005-06 were made up of the same participants who were 70 years in 2000-01; therefore, paired T-tests were used to investigate whether their self-assessed health was better or worse after five years. MANOVA analyses were then performed for each category to see if any independent variable affected the result. The Chi-square test was used to compare prevalence between groups. P-values $<0.05$ were considered significant. Analysis of change in self-assessed health in all subcategories for each age group was performed using ANOVA analyses, independent $T$-test, and paired samples $T$-test. SPSS for Mac, version 25, was used to perform statistical analysis after data transfer from SAS.

\section{Ethical Considerations}

The Prospective Population Study of Women in Gothenburg, Sweden was approved by the ethics committee of the University of Gothenburg and Regional Ethical Review Board in Gothenburg from 1968 and all later follow-up (latest DNr 258-16, 20160411). The studies comply with the Declaration of Helsinki and all participant consent was written informed consent.

\section{Results}

There was a decline in self-assessed health among 38year-old women in Gothenburg from 1992 to 2017. The deterioration of health was most apparent in the subcategories of social functioning, mental health, vitality, general health, and mental component summary scores. A deterioration in vitality was also shown among 50-year-old women.

\section{Analyses of Secular Trends in 38-, 50- and 70-Year-Old Women from 1992-1993 to 2016-2017}

The 38-year-old women showed a decrease in SF $(-10.2$ points), MH ( -5.9 points), VT (- 13.3 points), GH ( -10.2 points), and MCS ( -5.1 points) 1992 to 2016.50 -year olds showed an increase in PF ( +6.7 points), but a decrease in 
Table 2 Secular Trends in Self-Assessed Health, Selected Subcategories Among 38-, 50-, 70-75-Year-Old Women from 1992-1993 to 2017-2017

\begin{tabular}{|c|c|c|c|c|c|}
\hline 38 Years & Year of Birth & $\mathbf{n}$ & $\mathbf{M}$ & $95 \% \mathrm{Cl}$ & $\mathbf{p}$ \\
\hline Social functioning & $\begin{array}{l}1954 \\
1966 \\
1978\end{array}$ & $\begin{array}{l}69 \\
202 \\
262\end{array}$ & $\begin{array}{l}91.5 \\
85.6 \\
81.3\end{array}$ & $\begin{array}{l}87.7-95.3 \\
82.6-88.6 \\
78.6-83.8\end{array}$ & 0.001 \\
\hline Mental health & $\begin{array}{l}1954 \\
1966 \\
1978\end{array}$ & $\begin{array}{l}69 \\
201 \\
262\end{array}$ & $\begin{array}{l}78.3 \\
76.3 \\
72.4\end{array}$ & $\begin{array}{l}74.3-82.4 \\
73.7-78.9 \\
70.4-74.5\end{array}$ & 0.012 \\
\hline Vitality & $\begin{array}{l}1954 \\
1966 \\
1978\end{array}$ & $\begin{array}{l}69 \\
201 \\
262\end{array}$ & $\begin{array}{l}66.7 \\
60.5 \\
53.4\end{array}$ & $\begin{array}{l}62.0-71.5 \\
57.5-63.5 \\
50.9-55.9\end{array}$ & $<0.0001$ \\
\hline General health & $\begin{array}{l}1954 \\
1966 \\
1978\end{array}$ & $\begin{array}{l}69 \\
201 \\
261\end{array}$ & $\begin{array}{l}82 \\
78.5 \\
71.8\end{array}$ & $\begin{array}{l}77.7-86.3 \\
75.9-81.1 \\
69.5-74.2\end{array}$ & $<0.0001$ \\
\hline Mental component summary & $\begin{array}{l}1954 \\
1966 \\
1978\end{array}$ & $\begin{array}{l}68 \\
199 \\
255\end{array}$ & $\begin{array}{l}48.8 \\
46.5 \\
43.7\end{array}$ & $\begin{array}{l}46.3-51.3 \\
44.9-48 \\
42.4-45.1\end{array}$ & 0.001 \\
\hline \multicolumn{6}{|l|}{50 years } \\
\hline Physical functioning & $\begin{array}{l}1942 \\
1954 \\
1966\end{array}$ & $\begin{array}{l}99 \\
289 \\
306\end{array}$ & $\begin{array}{l}83.5 \\
87.8 \\
90.2\end{array}$ & $\begin{array}{l}79.4-87.7 \\
85.6-89.8 \\
88.6-91.7\end{array}$ & 0.002 \\
\hline Vitality & $\begin{array}{l}1942 \\
1954 \\
1966\end{array}$ & $\begin{array}{l}99 \\
287 \\
305\end{array}$ & $\begin{array}{l}64.6 \\
60.6 \\
57.0\end{array}$ & $\begin{array}{l}59.8-69.4 \\
58.0-63.2 \\
54.4-59.7\end{array}$ & 0.011 \\
\hline $70-75$ years & & & & & \\
\hline Physical role & $\begin{array}{l}1922 \\
1930\end{array}$ & $\begin{array}{l}285 \\
248\end{array}$ & $\begin{array}{l}68.7 \\
77.1\end{array}$ & $8.4(2.1-14.7)$ & 0.009 \\
\hline Emotional role & $\begin{array}{l}1922 \\
1930\end{array}$ & $\begin{array}{l}285 \\
246\end{array}$ & $\begin{array}{l}72.9 \\
82.6\end{array}$ & $9.7(3.6-15.6)$ & 0.002 \\
\hline
\end{tabular}

VT ( -7.6 points). Mean of RP (+8.4 points) as well as RE $(+9.7$ points $)$ scores increased in 70-year olds born in 1930 compared to those born in 1922, see Table 2. Women born in 1930 showed a significant decrease in their self-rated health in all subcategories of SF-36 from the age of 70 to 75 , that is, when comparing the studies in 2000 and 2005 (the results are not shown).

Table 3 and Figure 1 show variables that significantly associated the outcome of SF-36 in the respective subcategory in 38-, 50- and 70-year olds.

\section{Thirty-eight-Year Olds}

Mental stress and drinking beer were associated with SF. Women who never experienced mental stress in (group “i”) perceived higher SF (+12.4 points) than women who sometimes experienced mental stress (group "ii"/ +8.5 points) as well as women who regularly experienced mental stress (group "iii”). Women drinking beer sometimes (group “ii”) perceived higher SF (+3.6 points), both compared to women drinking beer more often (group “iii”) and never (group “i”/-6.3 points). Mental stress was also associated with $\mathrm{MH}, \mathrm{VT}, \mathrm{GH}$ and MCS; the less mental stress a woman experienced, the better scores at MH, VT, GH and MCS. Smoking was associated with $\mathrm{GH}$; smokers had lower perceived $\mathrm{GH}$ than non-smokers.

\section{Fifty-Year Olds}

Mental stress, education, socioeconomic status, BMI, and drinking beer were associated with PF. Women who never 
Table 3 All Variables That Significantly Affect the Outcome of SF-36 in the Respective Subcategory in 38-, 50- and 70-Year Olds

\begin{tabular}{|c|c|c|c|c|c|c|c|c|c|}
\hline & & PF & $\mathbf{R P}$ & SF & MH & RE & VT & GH & MCS \\
\hline \multicolumn{10}{|l|}{38 years } \\
\hline Mental stress & $\begin{array}{l}\text { Never } \\
\text { Sometimes } \\
\text { Regularly }\end{array}$ & & & $\begin{array}{l}+12.4 \\
+8.5 \\
0\end{array}$ & $\begin{array}{l}+14.0 \\
+11.0 \\
0\end{array}$ & & $\begin{array}{l}+19.7 \\
+16.9 \\
0\end{array}$ & $\begin{array}{l}+14.0 \\
+12.0 \\
0\end{array}$ & $\begin{array}{l}+8.0 \\
+5.8 \\
0\end{array}$ \\
\hline Smoking daily & $\begin{array}{l}\text { No } \\
\text { Yes }\end{array}$ & & & & & & & $\begin{array}{l}0 \\
-9.3\end{array}$ & \\
\hline Drinking beer & $\begin{array}{l}\text { Never } \\
\text { Sometimes } \\
\text { Regularly }\end{array}$ & & & $\begin{array}{l}-6.3 \\
+3.6 \\
0\end{array}$ & & & & & \\
\hline \multicolumn{10}{|l|}{50 years } \\
\hline Physical activity & $\begin{array}{l}\text { Inactive } \\
4 \mathrm{~h} / \mathrm{w} \\
\text { Regularly } \\
\text { Hard }\end{array}$ & & & & & & $\begin{array}{l}-25.0 \\
-16.0 \\
-11.0 \\
0\end{array}$ & & \\
\hline Mental stress & $\begin{array}{l}\text { Never } \\
\text { Sometimes } \\
\text { Regularly }\end{array}$ & $\begin{array}{l}+3.7 \\
+1.0 \\
0\end{array}$ & & & & & $\begin{array}{l}+17.0 \\
+13.1 \\
0\end{array}$ & & \\
\hline Education & $\begin{array}{l}\text { Elementary } \\
\text { Secondary } \\
\text { University }\end{array}$ & $\begin{array}{l}-7.3 \\
-1.9 \\
0\end{array}$ & & & & & & & \\
\hline SES & $\begin{array}{l}\text { Low } \\
\text { Middle } \\
\text { High }\end{array}$ & $\begin{array}{l}0 \\
+2.5 \\
+5.1\end{array}$ & & & & & & & \\
\hline BMI & With each increased unit & -0.84 & & & & & & & \\
\hline Drinking beer & $\begin{array}{l}\text { Never } \\
\text { Sometimes } \\
\text { Regularly }\end{array}$ & $\begin{array}{l}-1.8 \\
+2.0 \\
0\end{array}$ & & & & & & & \\
\hline \multicolumn{10}{|l|}{70 years } \\
\hline Physical activity & $\begin{array}{l}\text { Inactive } \\
4 \mathrm{~h} / \mathrm{w} \\
\text { Regularly } \\
\text { Hard }\end{array}$ & & $\begin{array}{l}-55,9 \\
-28.7 \\
-11.2 \\
0\end{array}$ & & & $\begin{array}{l}-39.7 \\
-13.1 \\
-7.2 \\
0\end{array}$ & & & \\
\hline Mental stress & $\begin{array}{l}\text { Never } \\
\text { Sometimes } \\
\text { Regularly }\end{array}$ & & $\begin{array}{l}+16.6 \\
+0.6 \\
0\end{array}$ & & & $\begin{array}{l}+22.8 \\
+12.5 \\
0\end{array}$ & & & \\
\hline BMI & With each increased unit & & -1.1 & & & & & & \\
\hline
\end{tabular}

Notes: Zero indicates reference value. Positive numbers indicate an increase in the number of points relative to the reference value. Negative numbers indicate a decrease in the number of points relative to the reference value.

Abbreviations: SF, social function; $\mathrm{MH}$, mental health; VT, vitality; $\mathrm{GH}$, general health; MCS, mental component summary.

experienced mental stress in (group "i”) perceived higher PF (+3.7 points) than women who sometimes experienced mental stress (group "ii"/+1.0 points) as well as women who regularly experienced mental stress (group “iii”). The higher education and SES a woman had, the higher PF she perceived. Women drinking beer sometimes (group "ii") perceived higher PF (+2.0 points), both compared to women drinking beer more often (group "iii") and never 


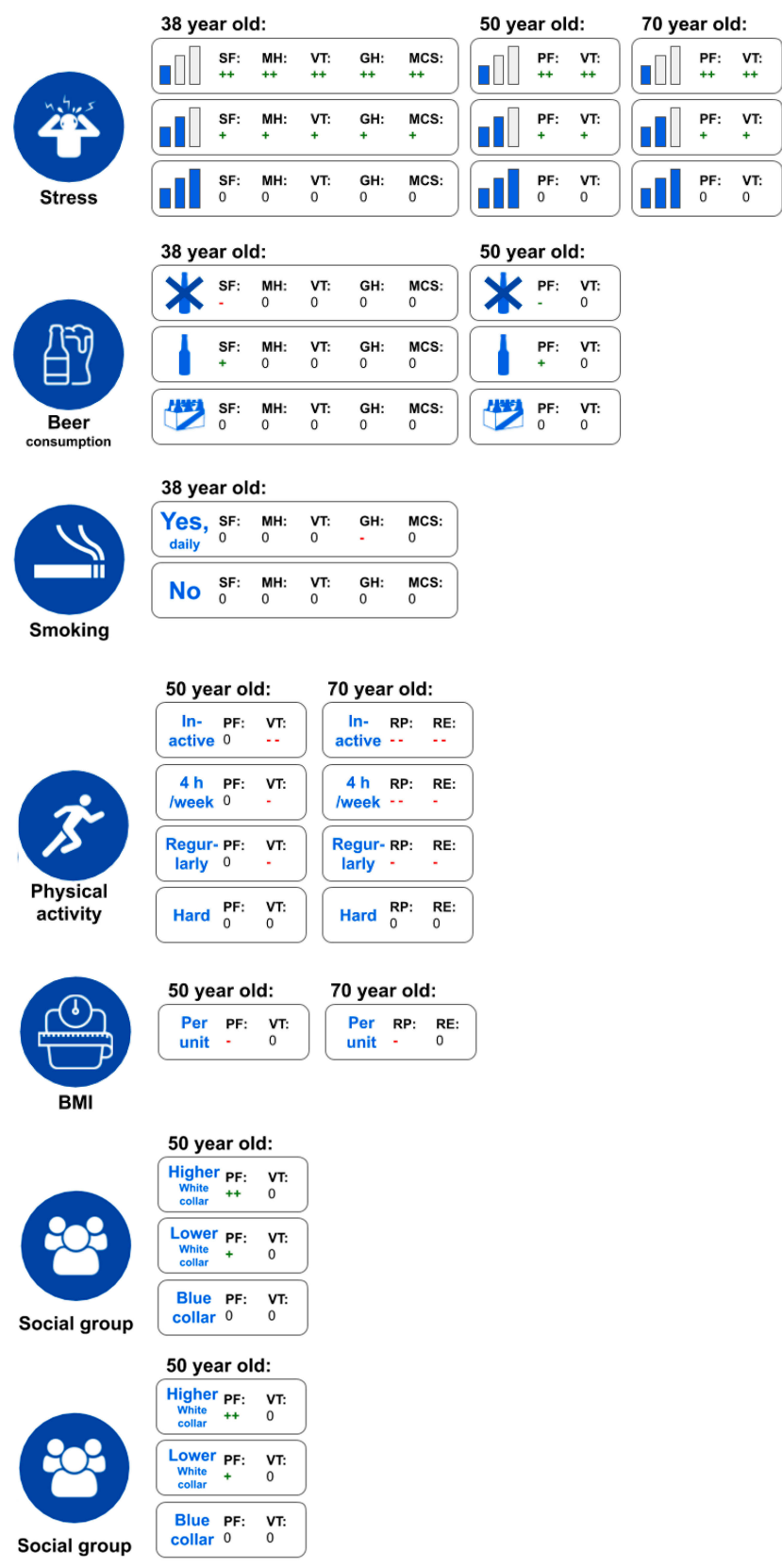

Figure I How the different variables significantly affect the outcome of SF-36 in the respective subcategory in 38-, 50- and 70-year olds. Mental stress, one bar includes mental stress levels 0 and I, two bars include mental stress level 2 and three bars include mental stress levels 3, 4 and 5. Beer drinking, crossed bottle includes drinking levels 0,1 and 2, one bottle includes drinking levels 3 and 4, a beer crate includes drinking levels 5 and 6 . Education, one bar includes education elementary school, two bars include upper secondary school and three bars include university. Zero indicates reference value. Positive numbers indicate an increase in the number of points relative to the reference value. Negative numbers indicate a decrease in the number of points relative to the reference value.

Abbreviations: SF, social function; $\mathrm{MH}$, mental health; VT, vitality; $\mathrm{GH}$, general health; MCS, mental component summary; PF, physical functioning; RP, physical role; RE, emotional role.

(group “i”/-1.8 points). Mental stress and physical activity were associated with VT. The more physical activity a woman performed a week, the higher VT she perceived.

\section{Seventy-Year Olds}

Mental stress, physical activity, and BMI were associated with RP. Women who never experienced mental stress (group "i") perceived higher RP (+16.6 points) than women who sometimes experienced mental stress (group "ii"/ +0.6 points) points as well as women who regularly experienced mental stress (group “iii”). The more physical activity a woman performed a week, the higher RP she perceived. Mental stress and physical activity were also associated with RE. Women who never experienced mental stress (group "i") perceived higher RE (+22.8 points) than women who sometimes experienced mental stress (group "ii"/+12.5 points) as well as women who regularly experienced mental stress (group "iii"). The more physical activity a woman performed a week, the higher RE she perceived.

\section{Discussion}

Our study shows that there has been a decline in selfassessed health among 38-year-old women in Gothenburg from 1992 to 2017. The deterioration of health was most apparent in the subcategories of social functioning, mental health, vitality, general health, and the Mental Component Summary. A deterioration in vitality was also shown among 50-year-old women. Our study also showed an improved self-assessed health among 50year-old women regarding physical activity and among 70year olds regarding the categories physical role and emotional role.

In the Swedish validation of the SF-36 survey in the 1990s, women had poorer self-assessed health than men, with the greatest differences observed in the age groups $30-40$ years and over 70 years. Poorer health profiles were associated with sociodemographic risk factors such as unemployment, low education, and divorce. ${ }^{20}$ Our study found that a lower level of education was associated with poorer physical functioning and more bodily pain among 50-year-old women. In the Swedish validation, poorer self-assessed general health was also associated with a greater use of healthcare. ${ }^{20}$ Self-assessed satisfaction with town health was strongly associated with general health and vitality reflecting both physical and mental health. High scores on vitality, mental health, and social function correlated positively with satisfaction regarding work, leisure, and communication with others. ${ }^{20}$ As 38 -year-old women today perceive themselves to be poorer on all of these subcategories than 24 years ago, this could mean that satisfaction with their own 
health, work and leisure has decreased and utilization of healthcare has increased. It is very possible that daily life activities have become more difficult to co-ordinate and that factors such as communication with others and leisure activities are eliminated, which affects health negatively. ${ }^{25}$ On the other hand, mean leisure time physical activity level have significantly increased for 38- and 50-year olds, during the same period. ${ }^{26}$

In a study from northern Sweden conducted between 1990 and 2014, women and men aged 24-34 could answer the question: "How would you rate your overall health condition when compared to people of your own age?", using the response options "better", "worse" or "similar". During this 24-year period, the proportion of women who responded "worse" increased from $8.5 \%$ in 1990 to $20 \%$ in 2014. The men's responses were in the opposite direction, with more men rating their health as "better". 27 The results of our study are consistent with this negative development among women. The Public Health Agency's annual report for 2017 also supports the current results, as $19 \%$ of women in Sweden between 16 and 84 years reported reduced mental well-being compared with $13 \%$ of all men. ${ }^{7}$

The significant increase in self-assessed stress levels in 38-year-old women is alarming, and self-assessed mental stress was associated with poorer outcomes in almost all the subcategories. The increasing mental stress among 38year-old women is in line with the Public Health Report for 2017 , where $18 \%$ of all people aged $30-44$ years reported "quite or much stress", whereas perceived mental stress was unchanged in people aged 45-64 and 65-84 years. Between 2006 and 2016, self-reported stress increased among both sexes, and by 2016, 18\% of all women indicated "quite or much stress" compared to $11 \%$ of all men. ${ }^{7}$ Earlier studies based on PSWG have previously demonstrated that the experience of mental stress more than doubled from the start of the study in 1968 to the study in $2004 .^{28,29}$

The Swedish Social Insurance Agency's statistics on sick leave also shows that mental stress in society has increased. Between 2010 and 2015, the number of persons on sick leave in Sweden increased by 98,000, where psychiatric diagnoses increased the most and accounted for $59 \%$ of the increase. Of these diagnoses, adjustment disorders and response to severe stress made up about half. In Sweden, stress-related illnesses have developed into a public health challenge. ${ }^{30-32}$

The fact that mental stress among middle-aged women in society has increased is probably due to many different factors, among which the work situation may be one. The county council sector accounts for the highest proportion of sick leave, while the lowest proportion is in the state and private sectors. In women-dominated occupations, an increase of excessive workload is reported, that is, a combination of high demands and low control at work. Public sector cuts that are strongly women-dominated increase workload when the same or greater work is done by fewer people. This increases the mental stress and influence over the work situation, which can be a contributory explanation for the increase in women's sickness absence and the prevalence of depressive symptoms in comparison with men. ${ }^{33}$

The advantages of this study are the longitudinal design as well as the high participation rate when following the 38-, 50- and 70-year-old women in the study 1992-93 until the study in 2016-17, using exactly the same examination protocol in all follow ups. The sample was large enough to represent different answers from the participants in PPSWG. This indicates that our findings are generalizable. A random sample of women in five age strata was studied, they were obtained from the Revenue Office Register and consisted of women born on certain dates. They were representative of the total female population in Gothenburg in these ages. We have not found other surveys using SF-36 for such a long follow-up time, but cross-sectional findings like "Measurement Properties and Normative Data" from Norway ${ }^{34}$ as well as from China ${ }^{35}$ may indicate that our findings can be seen outside Sweden.

There are some limitations to this study. Unfortunately, the participation rate has fallen and, for example, was down to $60 \%$ in $2004-05$, resulting in a lower degree of representativeness. Each woman participating must have a halfday free-time check-up. Probably, those women who care a lot about their health and have time to spend half a day are those who participate in the study, which may result in a higher self-assessed health compared to the general population. The women who experience a high level of stress and those who are sick are most likely not to participate. Moreover, the language in the questionnaire has shown in previous studies to be a limiting factor with regard to response rate, as all items are formulated in Swedish.

Future studies in the field are necessary to more clearly identify which groups of women indicate a significantly reduced self-assessed health, in order to tailor the prevention efforts according to their needs.

\section{Conclusion}

In summary, this study shows increased poor self-rated mental health among middle-aged women and increasing 
mental stress could be an important risk factor. It is important to raise awareness about women's risk of poor mental health in order to identify women at risk prior to the onset of disease and the need for sick leave. More individual information about the importance of recovery from their work, a reasonable level of physical activity, and reducing the number of stressors in life can help women to manage their everyday life. Our society needs more knowledge about increased poor mental health among middle-aged women in order to develop preventive measures, especially in primary health care.

\section{Acknowledgments}

This study was supported by grants from the Swedish state under the agreement between the Swedish government and the country councils, the ALF-agreement (68771).

\section{Author Contributions}

All authors contributed to data analysis, drafting or revising the article, gave final approval of the version to be published, and agree to be accountable for all aspects of the work.

\section{Disclosure}

The authors report no conflicts of interest in this work.

\section{References}

1. WHO Statistic [Internet]. 2019. Available from: https://www.who.int/ gho/publications/world_health_statistics/2019/en/. Accessed May 12, 2020.

2. Elofsson S, Unden AL, Krakau I. [Women's health deteriorated since 1993]. Lakartidningen. 1996;93(38):3233-3236. Swedish.

3. Hosseinpoor AR, Stewart Williams J, Amin A, et al. Social determinants of self-reported health in women and men: understanding the role of gender in population health. PLoS One. 2012;7(4):e34799. doi:10.1371/journal.pone.0034799

4. Boerma T, Hosseinpoor AR, Verdes E, Chatterji S. A global assessment of the gender gap in self-reported health with survey data from 59 countries. BMC Public Health. 2016;16:675. doi:10.1186/s12889016-3352-y

5. Gallicchio L, Hoffman SC, Helzlsouer KJ. The relationship between gender, social support, and health-related quality of life in a community-based study in Washington County, Maryland. Qual Life Res. 2007;16(5):777-786. doi:10.1007/s11136-006-9162-4

6. Statistiska centralbyrån. Var fjärde i Sverige är högutbildad. Stockholm: Statistiska centralbyrån (SCB); 2016 Available from: https:/www.scb.se/ hitta-statistik/sverige-i-siffror/utbildning-jobb-och-pengar/befolknin gens-utbildning/\#fordjupning. Accessed May 12, 2020.

7. Folkhälsomyndigheten. Folkhälsans utveckling årsrapport 2017 [Internet]. Stockholm: Folkhälsomyndigheten; 2017.

8. Försäkringskassan. Sjukfrånvarons utveckling 2016 [Internet]. Stockholm: Försäkringskassan; 2016.

9. Hakansson C, Lissner L, Bjorkelund C, Sonn U. Engagement in patterns of daily occupations and perceived health among women of working age. Scand J Occup Ther. 2009;16(2):110-117. doi:10.1080/ 11038120802572494
10. Eriksson HG, von Celsing AS, Wahlstrom R, Janson L, Zander V, Wallman T. Sickness absence and self-reported health a populationbased study of 43,600 individuals in central Sweden. BMC Public Health. 2008;8:426. doi:10.1186/1471-2458-8-426

11. Bengtsson C, Blohme G, Hallberg L, et al. The study of women in Gothenburg 1968-1969-a population study. General design, purpose and sampling results. Acta Med Scand. 1973;193(4):311-318. doi:10.1111/j.0954-6820.1973.tb10583.x

12. Bengtsson C, Hallberg L, Hallstrom T, et al. The population study of women in Goteborg 1974-1975-the second phase of a longitudinal study. General design, purpose and sampling results. Scand J Soc Med. 1978;6(2):49-54. doi:10.1177/140349487800600201

13. Bengtsson C, Gredmark T, Hallberg L, et al. The population study of women in Gothenburg 1980-81-the third phase of a longitudinal study. Comparison between participants and non-participants. Scand J Soc Med. 1989;17(2):141-145.

14. Bengtsson C, Ahlqwist M, Andersson K, Bjorkelund C, Lissner L, Soderstrom M. The prospective population study of women in Gothenburg, Sweden, 1968-69 to 1992-93. A 24-year follow-up study with special reference to participation, representativeness, and mortality. Scand J Prim Health Care. 1997;15(4):214-219. doi:10.3109/02813439709035031

15. Van Hook MP, Berkman B, Dunkle R. Assessment tools for general health care settings: PRIME-MD, OARS, and SF-36. primary care evaluation of mental health disorders. Older Americans resources and services questionnaire; short form-36. Health Soc Work. 1996;21 (3):230-234. doi:10.1093/hsw/21.3.230

16. Busija L, Pausenberger E, Haines TP, Haymes S, Buchbinder R, Osborne RH. Adult measures of general health and health-related quality of life: medical Outcomes Study Short Form 36-Item (SF-36) and Short Form 12-Item (SF-12) Health Surveys, Nottingham Health Profile (NHP), Sickness Impact Profile (SIP), Medical Outcomes Study Short Form 6D (SF-6D), Health Utilities Index Mark 3 (HUI3), Quality of Well-Being Scale (QWB), and Assessment of Quality of Life (AQoL). Arthritis Care Res (Hoboken). 2011;63 (Suppl 11):S383-412. doi:10.1002/acr.20541

17. McHorney CA, Ware JE Jr., Lu JF, Sherbourne CD. The MOS 36item Short-Form Health Survey (SF-36): III. Tests of data quality, scaling assumptions, and reliability across diverse patient groups. Med Care. 1994;32(1):40-66. doi:10.1097/00005650-19940100000004

18. Sullivan M, Karlsson J, Ware JE Jr. The Swedish SF-36 Health Survey-I. Evaluation of data quality, scaling assumptions, reliability and construct validity across general populations in Sweden. Soc Sci Med. 1995;41(10):1349-1358. doi:10.1016/0277-9536(95)00125-Q

19. Persson LO, Karlsson J, Bengtsson C, Steen B, Sullivan M. The Swedish SF-36 Health Survey II. Evaluation of clinical validity: results from population studies of elderly and women in Gothenborg. $J$ Clin Epidemiol. 1998;51(11):1095-1103. doi:10.1016/S0895-4356(98)00101-2

20. Sullivan M, Karlsson J. The Swedish SF-36 Health Survey III. Evaluation of criterion-based validity: results from normative population. J Clin Epidemiol. 1998;51(11):1105-1113.

21. Ware JE Jr. SF-36 Health Survey Manual and Interpretation Guide. 1993.

22. Taft C, Karlsson J, Sullivan M. Do SF-36 summary component scores accurately summarize subscale scores? Qual Life Res. 2001;10(5):395-404. doi:10.1023/A:1012552211996

23. Carlsson G. Socialgruppering: Social Mobility and Class Structure. Lund, Sweden: University of Lund, GWK Gleerup; 1958.

24. Sweden S Swedish Socioeconomic Classification. 1982.

25. Griep RH, Toivanen S, van Diepen C, et al. Work-family conflict and self-rated health: the role of gender and educational level. Baseline Data from the Brazilian Longitudinal Study of Adult Health (ELSABrasil). Int J Behav Med. 2016;23(3):372-382. 
26. Waller M, Lissner L, Hange D, Sund V, Blomstrand A, Bjorkelund C. Socioeconomic disparities in physical activity among Swedish women and trends over time - the population study of women in Gothenburg. Scand J Prim Health Care. 2018;1-9.

27. Waller Lidstrom M, Wennberg P, Lundqvist R, Forssen A, Waller G. Time trends of comparative self-rated health in adults aged 25-34 in the Northern Sweden MONICA study, 1990-2014. PLoS One. 2017;12(11):e0187896. doi:10.1371/journal.pone.0187896

28. Hange D, Mehlig K, Lissner L, et al. Perceived mental stress in women associated with psychosomatic symptoms, but not mortality: observations from the Population Study of Women in Gothenburg, Sweden. Int J Gen Med. 2013;6:307-315. doi:10.2147/IJGM.S42201

29. Bjorkelund C, Andersson-Hange D, Andersson K, et al. Secular trends in cardiovascular risk factors with a 36-year perspective: observations from 38- and 50-year-olds in the Population Study of Women in Gothenburg. Scand J Prim Health Care. 2008;26(3):140146. doi:10.1080/02813430802088403

30. Ulrik Lidwall CO-B. Sjukskrivning för reaktioner på svår stress ökar mest [Internet]. Stockholm: Försäkringskassan; 2016.
31. Försäkringskassan. Sjukfrånvarons utveckling 2017 sjuk-och rehabiliteringspenning [Internet]. Stockholm: Försäkringskassan; 2017.

32. Gunnar Ahlborg AH jr, Hadžibajramović E, Pettersson S et al. KART-studien: arbetsmiljö, stress och hälsa bland anställda vid Västra Götalandsregionen. Sammanfattning av de viktigaste slutsatserna i KART-rapporterna 2004-2010, vetenskapliga publikationer samt vissa kompletterande analyser. [Internet]. Göteborg: Institutet för stressmedicin, Västra Götalandsregionen; 2016.

33. Maria Albin AT. Theo Bodin Arbetsmiljö $i$ kvinnodominerade sektorer, Regeringsuppdrag att genomföra en förstudie inför utlysning av forskningsmedel. Stockholm: FORTE: Forskningsrådet för hälsa, arbetsliv och välfärd; 2015.

34. Garratt AM, Stavem K. Measurement properties and normative data for the Norwegian SF-36: results from a general population survey. Health Qual Life Outcomes. 2017;15(1):51. doi:10.1186/s12955-0170625-9

35. Li L, Wang HM, Shen Y. Chinese SF-36 Health Survey: translation, cultural adaptation, validation, and normalisation. $J$ Epidemiol Community Health. 2003;57(4):259-263. doi:10.1136/jech.57.4.259

\section{Publish your work in this journal}

The International Journal of General Medicine is an international, peer-reviewed open-access journal that focuses on general and internal medicine, pathogenesis, epidemiology, diagnosis, monitoring and treatment protocols. The journal is characterized by the rapid reporting of reviews, original research and clinical studies across all disease areas. The manuscript management system is completely online and includes a very quick and fair peer-review system, which is all easy to use. Visit http://www.dovepress.com/ testimonials.php to read real quotes from published authors. 